\title{
Impact of Phosphorus Levels and PSB Strains on Soil Microbial and Enzymatic Activities under Acidic Soils of North East India
}

\author{
M. Raghuveer ${ }^{1 *}$, Vishram $\operatorname{Ram}^{2}$ and Avinash Chandra Maurya ${ }^{1}$ \\ ${ }^{1}$ Department of Agronomy, Institute of Agricultural Sciences, BHU, Varanasi- 221005, India \\ ${ }^{2}$ School of Natural Resource Management, College of Post Graduate Studies, Central \\ Agricultural Unversity, Umiam, Meghalaya- 793103, India \\ *Corresponding author
}

\section{A B S T R A C T}

\begin{tabular}{|c|}
\hline Keywords \\
\hline $\begin{array}{l}\text { Phosphorus, PSB, } \\
\text { Soil microbial } \\
\text { activity, } \\
\text { Phosphatase } \\
\text { activity (PHA), } \\
\text { Dehydrogenase } \\
\text { activity (DHA). }\end{array}$ \\
\hline Article Info \\
\hline $\begin{array}{l}\text { Accepted: } \\
23 \text { May } 2017 \\
\text { Available Online: } \\
\text { 10 June } 2017\end{array}$ \\
\hline
\end{tabular}

Soil microorganisms are supportive in the transformation of soil phosphorus $(\mathrm{P})$ and are thus an important component of the soil $\mathrm{P}$ cycle. These are effective in releasing $\mathrm{P}$ both from inorganic and organic pools of total soil $\mathrm{P}$ through their respective solubilizing and also enhance the soil microbial and enzymatic activities. To evaluate this an agronomic trial was conducted with a local high yielding variety of rice (cv. Shahsarang) during 201213 kharif season to find out the influence of phosphorus levels and PSB strains on soil microbial and enzymatic activities at Barapani, Meghalaya in North Eastern India. The soil microbial carbon $(\mathrm{C})$, nitrogen $(\mathrm{N})$, phosphorus $(\mathrm{P})\left(454.05,70.35,17.22 \mu \mathrm{g} \mathrm{g}^{-1}\right)$ and dehydrogenase activity (DHA) were found significantly higher $\left(5.61 \mu \mathrm{g} \mathrm{TPF} \mathrm{g}^{-1} \mathrm{~h}^{-1}\right)$ at 60 $\mathrm{kg} \mathrm{P}_{2} \mathrm{O}_{5}$ ha $^{-1}$ dose than other levels of $\mathrm{P}$ and with inoculation of Pseudomonas sp. (481.19, $68.18,16.11 \mu \mathrm{g} \mathrm{g}^{-1}$ and $5.03 \mu \mathrm{g} \mathrm{TPF} \mathrm{g}^{-1} \mathrm{~h}^{-1}$ ), respectively. Interaction effect was found significant on soil microbial $\mathrm{C}, \mathrm{N}, \mathrm{P}$ activities and $\mathrm{DHA}$ at $60 \mathrm{~kg} \mathrm{P}_{2} \mathrm{O}_{5} \mathrm{ha}^{-1}$ when associated with Pseudomonas sp. Higher value of phosphatase activity (PHA) was found

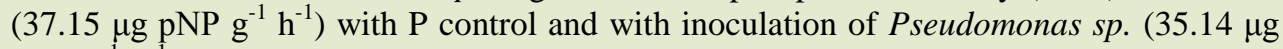
pNP $\mathrm{g}^{-1} \mathrm{~h}^{-1}$ ). The interaction of $\mathrm{P}$ control and Pseudomonas sp. was found significant for PHA. The main objective of this study was to assess the effect of P levels and PSB strains on soil microbial and enzymatic activities.

\section{Introduction}

Rice (Oryza sativa L.) occupies a pivotal place in Indian agriculture and it accounts for about 43 per cent of total food grain production and 55 per cent of cereals production in the country.

Nutrient management in rice is under submerged condition is a difficult practice. Phosphorus $(\mathrm{P})$ is the second most important macro-nutrient reported to be a critical factor of many crop production systems, due to its limited availability in soluble forms Xiao et $a l$. , (2011). It reacts with oxides/hydroxides to form stable forms that may not be available to plants, resulting low recovery and accumulation in soils Halajnia et al., (2009). Microorganisms play a major role in improving soil fertility. They are found to involve in transformation of soil $\mathrm{P}$ and are a part of soil $\mathrm{P}$ and are part of the soil $\mathrm{P}$ cycle. Soil microbial biomass plays a central role in the cycling and availability of phosphorus in soils Richardson and Simpson (2011). The microbial phosphorus pool is assumed to be 
quantitatively small, because most measurements have been made on agricultural soils that are enriched in phosphorus Clevel and Liptzin (2007). Almost half of the microorganisms in soil and plant roots possess $\mathrm{P}$ mineralization potential under the action of phosphatase Tarafdar et al., (1988). The largest portion of extra cellular soil phosphatase derived from the microbial population Dodor and Tabatabai (2003). In view of these facts, an experiment was undertaken at College of Post Graduate Studies, Central Agricultural University, Meghalaya during kharif season to determine the effect of phosphorus levels and PSB strains on the microbial and enzymatic activities under acidic conditions.

\section{Materials and Methods}

Experimental site and treatment
combination

The field experiment was conducted at Agricultural Research Farm of CPGS, CAU, Umiam, Meghalaya during kharif season of 2012. The experimental site was situated at $91^{\circ} 18^{\prime}$ to $92^{\circ} 18^{\prime} \mathrm{E}$ longitude and $25^{\circ} 40^{\prime}$ to $26^{\circ} 20^{\prime} \mathrm{N}$ latitude and at an altitude of $950 \mathrm{~m}$ above the mean sea level. The field experiment was laid out in split plot design with three replications.

Treatments consisted twenty combinations of 4 phosphorus levels $\left(0,20,40,60 \mathrm{~kg} \mathrm{P}_{2} \mathrm{O}_{5} \mathrm{ha}^{-1}\right)$ and 5 PSB strains (control, Arthrobacter sp., Enterobacter sp., Bacillus polymixia, Pseudomonas sp). Phosphorus levels assigned to main plots and PSB strains to sub-plots. The rice variety used for experiment was Shahsarang-1. Phosphorus was applied different levels according to treatments through SSP before transplanting of the seedlings. Seedlings were dipped into different cultures of strains for one night before transplanting according to PSB treatments.

\section{Soil microbial analysis}

Soils were sampled to a depth of $0-15 \mathrm{~cm}$ of the soil and were kept in refrigerator. The fresh samples were used for determination of soil microbial biomass carbon, nitrogen and phosphorus by the procedure chloroform fumigation extraction method Brookes and Joergensen (2006). Phosphatase activity (PHA) was determined in fresh samples as per the procedure described by Tabatabai and Bremner (1969) and dehydrogenasease activity (PHA) was determined in fresh samples as per the procedure described by Casida et al., (1964).

\section{Statistical analysis}

Main effects of phosphorus levels, PSB strains, as well as their interactions were tested by using the Fisher's method of analysis of variance technique as described by Gomez and Gomez (1983).

\section{Results and Discussion}

Soil microbial biomass carbon, nitrogen and phosphorus ( $\mu \mathrm{g} \mathrm{g}^{-1}$ (dw) soil)

The results (Table 1) revealed that, the soil microbial biomass carbon $\left(454.05 \mu \mathrm{g} \mathrm{g}^{-1}(\mathrm{dw})\right.$ soil), nitrogen (70.35 $\mu \mathrm{g} \mathrm{g}^{-1}$ (dw) soil) and phosphorus (17.22 $\mu \mathrm{g} \mathrm{g}^{-1}(\mathrm{dw})$ soil) were maximum with the application of $60 \mathrm{~kg} \mathrm{P}_{2} \mathrm{O}_{5}$ $\mathrm{ha}^{-1}$ over rest of the $\mathrm{P}_{2} \mathrm{O}_{5}$ levels. The inoculation of PSB strains caused significant variance on soil microbial biomass $\mathrm{C}, \mathrm{N}$ and P. The results (Table 1) showed that the inoculation of Pseudomonas sp., recorded the highest soil microbial biomass carbon and phosphorus (481.19 and $16.11 \mu \mathrm{g} \mathrm{g}^{-1}$ (dw) soil) was superior over control and Enterobacter sp., but was at par with Arthrobacter sp. and Bacillus polymixia. The soil microbial biomass nitrogen was found higher (68.18 $\mu \mathrm{g} \mathrm{g}^{-1}$ (dw) soil) with the 
inoculation of Pseudomonas sp., was superior (Table 2) over rest of the strains. The application of $20 \quad \mathrm{~kg} \quad \mathrm{P}_{2} \mathrm{O}_{5} \quad \mathrm{ha}^{-1}$ with association of Arthrobacter sp. achieved higher SMBC values $\left(581.95 \mu \mathrm{g} \mathrm{g}^{-1}(\mathrm{dw})\right.$ soil) as interaction effect was found significant (Table 2).

The interaction effect was found significant on SMBN, SMBP where, the application of $60 \mathrm{~kg} \quad \mathrm{P}_{2} \mathrm{O}_{5} \quad \mathrm{ha}^{-1}$ when inoculated with Pseudomonas sp. obtained maximum (95.68 and $18.91 \mu \mathrm{g} \mathrm{g}^{-1}(\mathrm{dw})$ soil) SMBN and SMBP readings (Table 2 ).

\section{Enzymatic activity}

The phosphorus control treatment recorded the highest phosphatase activity $(37.15 \mu \mathrm{g}$ pNP g ${ }^{-1} h^{-1}$ ) was superior over rest of P levels (Table 1). The highest phosphatase activity was observed with the inoculation of Pseudomonas sp. $\left(35.14 \mu \mathrm{g} \mathrm{pNP} \mathrm{g}{ }^{-1} \mathrm{~h}^{-1}\right)$ was superior over control, Enterobacter sp., and Arthrobacter sp., but was at par with Bacillus polymixia (Table 1).

The interaction effect of $\mathrm{P}$ levels and PSB strains was significant on PHA (Fig. 1) and

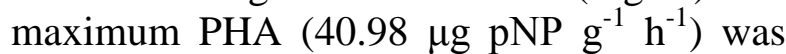
found by $\mathrm{P}$ control when was inoculated with Pseudomonas sp. The results (Table 1) revealed that, the highest $\left(5.61 \mu \mathrm{g}\right.$ TPF g $\left.{ }^{-1} \mathrm{~h}^{-1}\right)$ dehydrogenase activity was observed with the application of $60 \mathrm{~kg} \mathrm{P}_{2} \mathrm{O}_{5} \mathrm{ha}^{-1}$ over rest of the $\mathrm{P}_{2} \mathrm{O}_{5}$ levels.

The inoculation of Pseudomonas sp. recorded highest dehydrogenase activity $(5.03 \mu \mathrm{g}$ TPF $\mathrm{g}^{-1} \mathrm{~h}^{-1}$ ) was superior over PSB control and Enterobacter sp., but was at par with Arthrobacter sp. and Bacillus polymixia (Table 1). The significantly higher DHA observed by $60 \mathrm{~kg} \mathrm{P}_{2} \mathrm{O}_{5} \mathrm{ha}^{-1}$ when was associated with Pseudomonas sp. (Fig. 1).
Soil microbial biomass carbon, nitrogen and phosphorus $\left(\mu \mathrm{g} \mathrm{g}^{-1}(\mathrm{dw})\right.$ soil)

The microbial activity increased might be due to diverse substrate availability and moisture content in soils of lowlands round the year supported higher MBC in comparison to that in other rice ecosystems. Soil microbiota governs the available pools of nutrients in rice ecosystems. Soil microbial biomass carbon is a relatively liable fraction of organic matter is a key site for mineralization of organic $\mathrm{P}$ in soils and thus, a central feature in the $\mathrm{P}$ cycle Brookes et al., (1984). Phosphorus dynamics in soil and maintenance of its adequate supply are important for sustainability of native and agricultural ecosystems. Soil microbial biomass nitrogen contributes the largest fraction of the biologically active $\mathrm{N}$ pool in soil Jenkinson and Parry (1989) and the content is depended on quantity, quality and distribution of carbon inputs in soil that may vary with times and depth Kaiser and Heinemeyer (1993). Soil microbial biomass phosphorus is considered an important source of $\mathrm{P}$ for plant uptake Macklon et al., (1997) in P- fixing soils Ayaga et al., (2006). Microorganisms have a fundamental role in the biogeochemical cycles of the elements and in the formation of soil structure Roldan et al., (1994), such that it is widely accepted that a high level of microbial activity is necessary for the maintenance of an adequate quality of soil.

\section{Enzymatic activity}

The result was supported by findings of Araujo et al., (2008), might be due to the application of high dose of inorganic phosphorus in soil supplies adequate amount of available phosphorus to plants, which restricts the activity of phosphatase and helps in mineralization of total phosphorus present in the soil. 
Fig.1 Interaction effect of phosphorus levels and PSB strains on PHA and DHA of soil

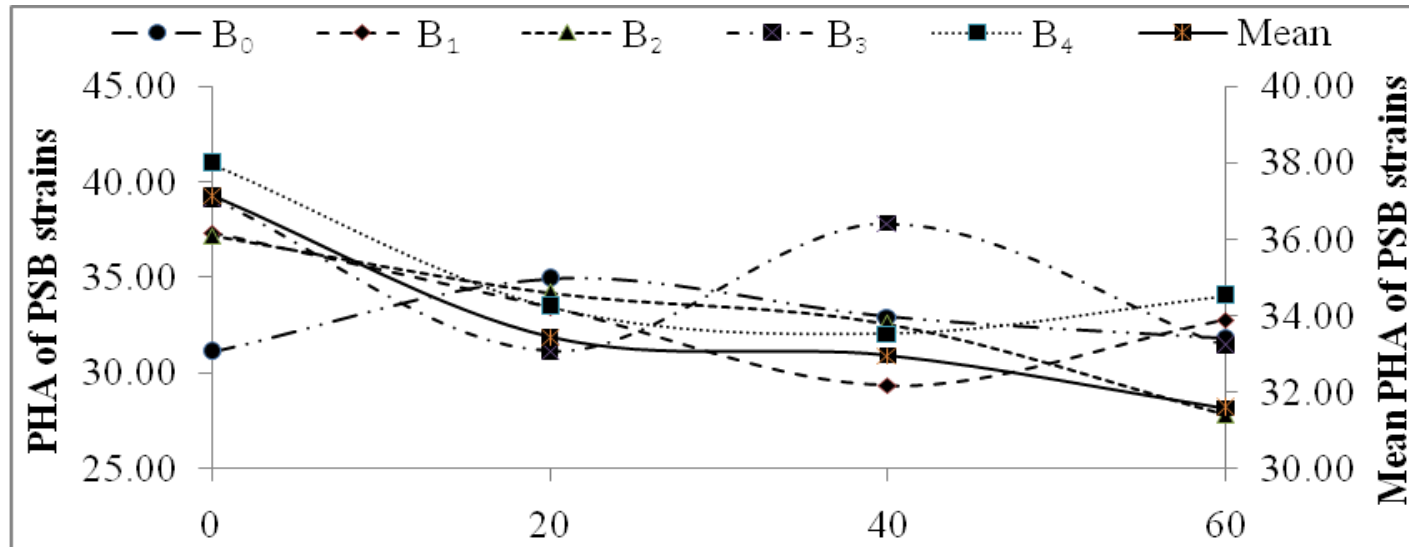

Phosphorus levels

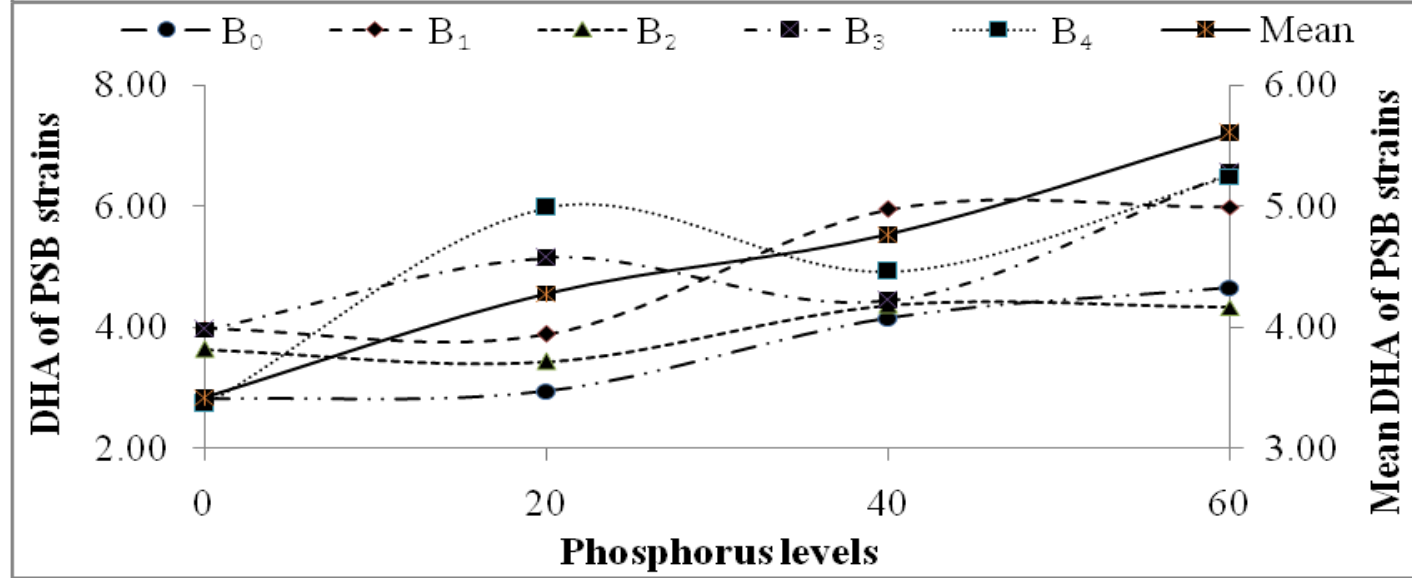

Table.1 Effect of phosphorus levels and PSB strains on microbial and Enzymatic activities of soil

\begin{tabular}{|c|c|c|c|c|c|}
\hline & $\begin{array}{l}\text { SMBC } \\
\left(\mu g^{-1}\right)\end{array}$ & $\begin{array}{l}\text { SMBN } \\
\left(\mu g^{-1}\right)\end{array}$ & $\begin{array}{l}\text { SMBP } \\
\left(\mu g^{-1}\right)\end{array}$ & $\begin{array}{c}\text { PHA } \\
\left(\mu \mathrm{g} \mathrm{pNP} \mathrm{g} \mathrm{g}^{-1} \mathrm{~h}^{-1}\right)\end{array}$ & $\begin{array}{c}\text { DHA } \\
\left(\mu \mathrm{g} \mathrm{TPF} \mathrm{g}^{-1} h^{-1}\right)\end{array}$ \\
\hline \multicolumn{6}{|c|}{ Phosphorus levels } \\
\hline $\mathbf{P}_{\mathbf{0}}$ & 442.73 & 54.49 & 12.31 & 37.15 & 3.42 \\
\hline $\mathbf{P}_{1}$ & 444.99 & 56.61 & 15.60 & 33.44 & 4.28 \\
\hline $\mathbf{P}_{2}$ & 450.74 & 57.66 & 16.26 & 32.96 & 4.77 \\
\hline $\mathbf{P}_{3}$ & 454.05 & 70.35 & 17.22 & 31.59 & 5.61 \\
\hline S.Em \pm & 0.94 & 0.56 & 0.29 & 0.79 & 0.19 \\
\hline $\mathrm{CD}(\mathrm{P}=\mathbf{0 . 0 5})$ & 3.26 & 1.95 & 1.00 & 2.75 & 0.64 \\
\hline \multicolumn{6}{|l|}{ PSB strains } \\
\hline $\mathbf{B}_{0}$ & 362.98 & 54.71 & 14.44 & 32.72 & 3.64 \\
\hline $\mathbf{B}_{1}$ & 468.68 & 58.69 & 15.57 & 33.23 & 4.95 \\
\hline $\mathbf{B}_{2}$ & 448.25 & 55.41 & 14.87 & 32.95 & 3.94 \\
\hline $\mathbf{B}_{3}$ & 479.55 & 61.90 & 15.77 & 34.89 & 5.03 \\
\hline $\mathbf{B}_{4}$ & 481.19 & 68.18 & 16.11 & 35.14 & 5.03 \\
\hline S.Em \pm & 9.04 & 0.81 & 0.20 & 0.60 & 0.18 \\
\hline $\mathrm{CD}(\mathrm{P}=\mathbf{0 . 0 5})$ & 26.04 & 2.33 & 0.58 & 1.73 & 0.52 \\
\hline Interaction & $*$ & $*$ & $*$ & $*$ & $*$ \\
\hline
\end{tabular}

*Interaction significant 
Table.2 Interaction effect of phosphorus levels and PSB strains on SMBC, SMBN and SMBP $\left(\mu \mathrm{g} \mathrm{g}^{-1}\right.$ (dw) soil)

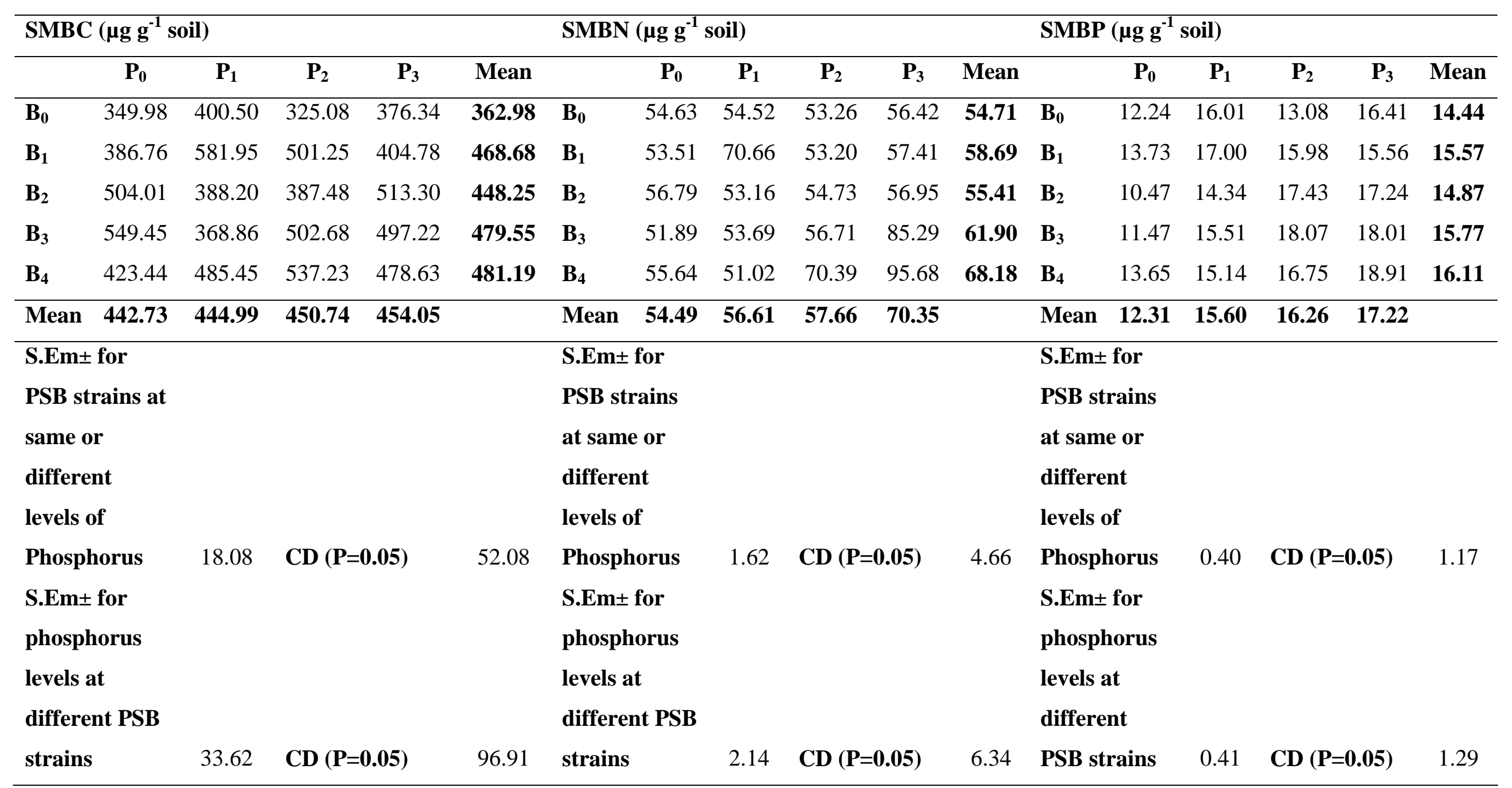


Results indicated that the application of agrochemicals significantly inhibits the population of phosphate solubilizers and nitrogen fixers, which was reported earlier by Balamurugan et al., (2010). It may be stated that the increase in phosphatase activity in PSB-treated soil is an indication of the increased soil fertility and improvement in the phosphate solubilization. The increase in DHA might be due to application of phosphorus increases the microbial population in rhizosphere of plant and PSB inoculation increased as compared to control treatment Duarah et al., (2011). The dehydrogenase activity of soil in case of both rice and bean cultivation was found to be decreased with the amendment of NPK fertilizer. In contrast to this, a significant increase of dehydrogenase activity $(p \leq 0.05)$ was found in PSB treated (without NPK treatment) soil over the control. Dehydrogenase activity is commonly used as an indicator for biological activity, i.e., it can be used to indicate the total microbial population Duarah et al., (2011). However, the decrease in dehydrogenase activity may also be contributed by the fact that indicator TTC (triphenyltetrazolium chloride) yield less formazan for the interference by the NPK with the electron donors Casida (1977).

The soil microbial and enzymatic activities were significantly influenced by application of phosphorus levels and highest values recorded with $60 \mathrm{~kg} \mathrm{P}_{2} \mathrm{O}_{5} \mathrm{ha}^{-1}$ over other $\mathrm{P}$ levels. The soil microbial and enzymatic activities were recorded significantly higher with the inoculation of Pseudomonas sp. The interaction effect was found significant on soil microbial and enzymatic activities.

\section{Acknowledgements}

Authors wish to acknowledge Dr. P.K. Bora, School incharge, SNRM, Dr. D. Thakuria, Associate Professor, College of post Graduate
Studies, Umiam, Dr. Rajesh Kumar, Senior Scientist, ICAR, Research complex for NEH region, Umiam and Er. Lala I.P. Ray, Assistant Professor, College of Post Graduate Studies for their support to carry out this work.

\section{References}

Araujo, A. P., C. Plassard and Drevon, J. J. 2008. Phosphatase and phytase activities in nodules of common bean genotypes at different levels of phosphorus supply. Plant Soil. 312: 129-138.

Ayaga, G., A. Todd and Brookes, P.C. 2006. Enhanced biological cycling of phosphorus increases its availability to crops in low-input sub-saharan farming systems. Soil Biology and Biochemistry. 38: 81-90.

Balamurugan, A., T. Princy, R. V. Pallavi, P. R. Nepolean Jayanthi and Premkumar, R. 2010. Isolation and characterization of phosphate solubilising bacteria in tea (Camellia sinensis). Journal of Biological Science Research 1(4): 285293.

Brookes, P. C. and Joergensen, R. G. 2006. Microbial biomass measurements by fumigation extractant. In: Bloem $\mathrm{J}$, Hopkins D W and Benedetti A (ed) Microbiological methods for assessing soil quality. CABI publishing, Oxfordshire, UK, pp. 77-83.

Brookes, P. C., D. S. Powtson and Jenkinson, D. S. 1984. Phosphorus in the soil microbial biomass. Soil Biology and Biochemistry. 16: 169-175.

Casida, L. E. Jr. 1977. Microbial metabolic activity in soil as measured by dehydrogenase determinations. Applied Environmental Microbiology. 34(6): 630-636.

Casida, L. E. Jr., D. A. Klein and Sautoro, T. 1964. Soil dehydrogenase activity. Soil 
Science. 98: 371-376.

Clevel, C. C. and Liptzin, D. 2007. C: N: P stoichiometry in soil: is there a "Redfield ratio" for the microbial biomass? Biogeochemistry. 85: 235252.

Dodor, D. E. and Tabatabai, A. M. 2003. Effect of cropping systems on phosphatases in soils. Journal of Plant Nutrition and Soil Science. 166: 7-13.

Duarah, I., M. Deka, N. Saikia and Deka Boruah, H.P. 2011. Phosphate solubilizers enhance NPK fertilizer use efficiency in rice and legume cultivation. Biotechnology. 1: 227-238.

Gomez, K. A. and Gomez, A. A. 1983. Statistical procedures for Agriculture research, $2^{\text {nd }}$ edn. John Wiley and Sons Inc, New York.

Halajnia, A., G. H. Haghhnia and Fotovat, A. 2009. Phosphorus fractions in calcareous soils amended with $\mathrm{P}$ fertilizer and cattle manure. Geoderma. 150: 209-213.

Jenkinson, D. S. and Parry, L. C. 1989. The nitrogen cycle in the broad balk wheat experiment: a model for the turnover of nitrogen through the soil microbial biomass. Soil Biology and Biochemistry. 21: 535-541.

Kaiser, E. A. and Heinemeyer, O. 1993. Seasonal variations of soil microbial biomass carbon within the plough layer. Soil Biology and Biochemistry. 24:
675-683.

Macklon, A. E. S., S. J. Grayston, C. A. Shand, A. Sim, S. Sellars and Ord, B. G. 1997. Uptake and transport of phosphorus by Agrostis capillaris seedlings from rapidly hydrolysed organic sources extracted from 32Plabelled bacterial cultures. Plant Soil. 190: 163-167.

Richardson, A. E. and Simpson, R. J. 2011. Soil microorganisms mediating phosphorus availability. Plant Physiology. 156: 989-996.

Roldan, A., F. Garcia-Orenes and Albaladejo, J. 1994. Microbial populations in the rhizosphere of the Brachypodium retusum and their relationship with stable aggregates in a semi-arid soil of southern Spain. Arid Land Research Management. 8: 105-114.

Tabatabai, M. A. and Bremmer, J. M. 1969. Use of p-nitrophenyl phosphate for assay of soil phosphotase activity. Soil Biology and Biochemistry. 1: 301-307.

Tarafdar, J. C., A. V. Rao and Bala, K. 1988. Production of phosphatases by fungi isolated from desert soils. Folia Microbiology. 33: 453-457.

Xiao, C. Q., R. A. Chi, X. H. Li, M. Xia and Xia, Z. W. 2011. Biosolubilization of rock phosphate by three stress-tolerant fungal strains. Applied Biochemistry and Biotechnology. 165: 719-727.

\section{How to cite this article:}

Raghuveer, M., Vishram Ram and Avinash Chandra Maurya. 2017. Impact of Phosphorus Levels and PSB Strains on Soil Microbial and Enzymatic Activities under Acidic Soils of North East India. Int.J.Curr.Microbiol.App.Sci. 6(6): 2061-2067. doi: https://doi.org/10.20546/ijcmas.2017.606.244 